\title{
Social Networks and the Circulation of Technology and Knowledge in the Global Spanish Empire
}

\author{
Bartolomé Yun-Casalilla
}

Is it possible to think of a global empire where there is not a substantial circulation of technology and technological knowledge? Can we imagine the sixteenth and seventeenth-century scientific revolution without the circulation of knowledge and objects which made it possible and without the most important space for such circulation? This is what Masson de Morvillers did when, referring to scientific development in a famous

This work has been carried out within the framework of the activities of the research group 'Globalización Ibérica: Redes entre Asia y Europa y los cambios en las pautas de consumo en Latinoamerica. HAR2014-53797-P', as well as of GECEM ('Global Encounters between China and Europe: Trade Networks, Consumption and Cultural Exchanges in Macau and Marseille, 1680-1840') project hosted by the Pablo de Olavide University, UPO (Seville, Spain). The GECEM project is funded by the ERC (European Research Council)-Starting Grant, under the European Union's Horizon 2020 Research and Innovation Programme, ref. 679371, www.gecem.eu. The P.I. (Principal Investigator) is Professor Manuel Perez Garcia (Distinguished Researcher at UPO).

B. Yun-Casalilla $(\bowtie)$

Pablo de Olavide University, Seville, Spain

(C) The Author(s) 2018

M. Perez Garcia and L. de Sousa (eds.), Global History and New

Polycentric Approaches, Palgrave Studies in Comparative Global History, https://doi.org/10.1007/978-981-10-4053-5_13 
article in L'Encyclopédie Méthodique, he wrote 'in two centuries, in four, or even in six, what has Spain done for Europe?' Spain, he added, is a country where it is necessary 'to ask priests for permission to read and think' (Masson de Movillers 1782: 575).

This chapter aims at drawing attention to the role of the Spanish Empire in the circulation of technology and technological knowledge during this epoch. It focuses on the role of informal institutions and social networks regulating such circulation and examines the relationship between political power and the control of technological knowledge, as well as the often-simplified interplay between globalization and empire.

\section{Iberia And the Empire: Channels of KNOWledge}

A new image of the technological development in the Spanish Golden Age has emerged since 1988, when David Goodman published his influential Power and Penury (Goodman 1988). This book made clear the interest of Philip II (1527-1598) in mining technology, metallurgy, navigation, mathematics, medicine and many other sciences. Goodman's research aimed at defending the image of the king as a patron of science and technological development. But the book also wanted to change the stereotype of the 'Castilians as uninterested in technology and science' (Goodman 1988: 264). Three decades of further research has corroborated the idea of significant scientific development in Spain and has also stressed the importance of fields not directly linked to the king's action. In an attack against the traditional view, Eamon (2009) has summarized this new view and has shown the Black Legend's Prejudices that underlay previous and negative stereotypes. This contrasts with a recent and simplistic vision that still emphasizes the idea of Spain as an absolutist state and of its monarchy as able to abort the rise of positive institutions (Acemoglu, Jonson and Robinson 2005).

This new less biased image has still neglected the study of the role of the circulation of goods and, more importantly for us, that of technological awareness as the base for technological progress. Regarding to this aspect I propose to start by taking into account also the role of informal institutions, based on personal relationship, in such a circulation.

One has to consider that the Iberian Peninsula was from the tenth century onwards a privileged area of intercultural exchange. Inventions or the use of inventions such as the compass and gunpowder, and 
scientific developments in fields like trigonometry, cartography or mathematics provided the base for overseas expansion in the fifteenth century. We also need to remember that this was the outcome of a cross-fertilizing convergence in this area of Hebrew, Islamic and Christian webs of knowledge that can be followed into Asia. These were already the product of a globalizing process. Even the caravel, apparently a genuine Iberian product, was the result of the confluence in Iberia of navigation techniques from Northern and Southern Europe. ${ }^{1}$

This crossroads character of the Iberian Peninsula did not disappear; on the contrary, it intensified during the sixteenth century. Some scholars have rightly underlined the negative effects for scientific and technological development of the Jews' expulsion in 1492 and the prosecution and final deportation in 1608-1609 of the moriscos. It is also impossible to forget the negative effects of the Inquisition on creative thinking. But it is also true that by the sixteenth century, Iberia had become the core of a dispersed European composite monarchy. This implied the strengthening of the previous social and intellectual networks on which knowledge, goods inspiring provocative thinking, technology and technicians, architects and engineers, pilots and seamen, soldiers familiar with warfare technology, geometry, mathematics and medical practitioners fluidly circulated. It is even possible that this created different and complementary types of networks from those studied by L. Epstein and others when putting the accent on the role of guilds and artisans for the diffusion of technological knowledge and know-how, of which an important precondition is religious tolerance. Of course, this type of network was not entirely absent from the Iberian Peninsula, at least until the beginning of the seventeenth century. We need to consider that communications with Italy, a Catholic country and maybe the core of technological developments until c. 1600, were very intense. Furthermore, the deportation of hundreds of moriscos within the Iberian Peninsula after the war of the Alpujarras (1568-71) contributed to the spread of technologies in the textile and the building sectors. But more importantly, this dispersed composite monarchy used patronage to form a web of aristocrats and elites from Iberia to Austria, Italy and the Low Countries, which facilitated the circulation of ideas, technicians, engineers, architects, medical practitioners and others. Maybe the most prominent example is Juanello Turriano, the architect, engineer and technician (including the art of clock-making) who would seek Charles V's protection (Zanetti 2017). ${ }^{2}$ We know today that, in spite of the identification between book culture and the Protestant 
Reform, these networks were crucial for the circulation of books (and not only on theology or religion), imprints, engravings and maps, which were agents for the circulation of knowledge. The aristocrats, the nonnoble letrados and all types of literate people circulated books on geometry and mathematics (essential for the art of war), geography and history (also in many cases linked to war), engineering, pharmacopoeia, natural history and many other disciplines that were the basis for the diffusion of new technological knowledge, as well as for intellectual creativity in many different fields. These networks were interlinked by embassies, through consular agents, many of them traders, priests, or members of religious orders, and were also webs for the circulation of exotica, news, tools and cultural goods of great importance in the development of technological curiosity and information (Aram and Yun-Casalilla 2014).

These networks were increasingly dense as Castile became the centre of a global empire in need of new knowledge. We have considerable evidence that it is just the tip of the iceberg of something that deserves more systematic research. For example, it should be noted that many of the proponents of inventions to the king were non-Spanish and non-peninsular subjects of the Habsburgs (Tapia 1990). They were often Italians, which confirms the existence of a still-vivid Catholic technological world. But one can also find Germans, Flemish, Dutch and Europeans from many other regions. Crucial sectors, such as mining, were very active in attracting German experts, whose knowledge was productively absorbed (Sánchez Gómez 1989). But mining is even more meaningful in relation to these transnational and global connections if we consider that the Welser and the Fugger obtained the monopoly concession to exploit the mines of Almaden, thus promoting the migration of technicians from Central Europe to Spain (Kellenbenz 1999).

These transnational webs readily acquired a transatlantic dimension. Of the inventions for which permission to be introduced in America was sought between c. 1550 and 1600, some were promoted by nonSpanish, which is very revealing. ${ }^{3}$ For obvious reasons, mining, and silver mining in particular, was a privileged sector for the diffusion of European technology to America (Bakewell 1976, 1989). Again, the examples of the Fugger and Welser are very pertinent (Sánchez Gómez 1989). Although the initial conquest of America was based on unsophisticated military technology, crucial knowledge generated by the European military revolution was also transferred to the New World (Headrick 2010: chapter II). Though it is a subject for further research, 
there are many sings of the diffusion of artisanal techniques in fields like building, the textile sector, metallurgy, woodwork, paper production and many others. The very sociology of the (legal) emigrants to Spanish America, many of them artisans, shows the importance of technological and know-how transferences. The demographic boom of villages such as Puebla in Mexico was brought about by the arrival of textile workers from Brihuega, a very important textile centre in Castile (Altman 2000). Strategically important techniques in Europe, such as the production of hemp for transport and shipbuilding, were introduced in the New World where ecological constrictions permitted. The development of the plantation economy obliged to export to the New World inventions and machines, such as the ingenio or trapiche for sugar production. And we need to stop here to abbreviate a long list.

America and Ibero-America in particular were the epicentre for the diffusion of knowledge which revolutionized the world of technology and sciences on a global scale. The knowledge of new crops and their cultivation techniques, like corn, tobacco, yucca (cassava or manioc) or the potato, had an impressive global and sometimes immediate impact in Europe, Asia and Africa (Russell-Wood 1998). Sectors such as dyeing were dramatically changed by the use of new dyes and techniques such as palo campeche, indigo or cochineal. Botany seems to have changed in Europe thanks to people like Nicolás Monardes and García de Orta. The collections of European aristocrats and princes incorporated much American exotica destined to become the bases for new ways of classifying and understanding nature and the possible human action upon it. Medical practitioners such as Francisco Hernández, protomédico of Philip II, were sent by the king in search of health remedies, which gives an idea of a top-down development of knowledge in which official formal institutions were very interested. But others, such as Monardes, undertook such studies proprio motu and thanks to personal networks, in this case strongly articulated through informal merchant and family connections (Yun-Casalilla 2014). All of this provided the foundations for more empirical knowledge, which paved the way for Baconian approaches to nature (Osorio 2006). ${ }^{4}$ The influence not only on scientific knowledge but also on the relationship between basic and applied knowledge was really notable.

The circulation of techniques, knowledge and know-how flowed in many different and opposite directions and not only between Europe and America. The Spanish enhanced and created circuits for such 
diffusion in America. The Spanish conquerors extended the production techniques for yucca from the Caribbean to the Magdalena valley, while also spreading the mate herb and the techniques for its production. Many other examples could be added (Saldarriaga 2011).

This process had a twofold effect.

First, the Habsburg composite monarchy enhanced the most efficient corridors ever known before for the transnational and global ciculation of knowledge and technology. This was possible thanks to the ramifications of the monarchy in America and then, after the incorporation of Portugal and its empire in 1580, also in Africa and Asia. Although some of these facts are well known, considering them together gives us a richer image of what was happening. Many of these corridors already existed. They were very active in the Indian Ocean, in the Sea of China and even within the Americas. The connections between the Spanish and the Portuguese were also strong even before 1580. But the impulse given by the political connections interlinked previous spheres of exchange and even extended beyond the political frontiers of the Empire. Technological globalization was in part a consequence of the rise of empire building, yet went beyond it.

Second, we need to bear in mind that the circulation of knowledge provides a basis for the production of new knowledge. Medicine is a good example. Texts such as the Discursos medicinales written by the Spanish doctor Juan Méndez Nieto show the possibilities of crossfertilization between American medicine and the use of local herbs in European medical practices. Even more importantly, these contacts facilitated synergies among apparently different fields of knowledge. The works of Juan de Cárdenas, who studied at the University of Mexico, for example, prove the potentialities of the dialogue between theoretical knowledge, natural history and mining, and reveal the many possibilities during the epoch for the conjunction between theory and practice (Osorio 2006: 75-79). In the mining sector, Julio Sánchez Gómez has shown how the 'contact of Central European and American experiences' produced improvements in Spain that would remain 'unknown in Central Europe until two hundred years later' (Sánchez Gómez 1989: 728).

We do not know to what extent this was the case in other sectors. But it is tempting to think that this circulation of knowledge in the Iberian Peninsula, which as noted above had been very active since the medieval period, is one of the reasons for heretofore disregarded pieces of European history that could change our image of Spanish technological development in the sixteenth century. To my knowledge, no historian 
has ever noted that a good deal of the projects presented to the English crown as inventions, were based on the introduction of techniques imported from Spain. This is the case of techniques for the production of leather, felt hats, needles, earthen pots and portable ovens, soap, silk stockings and others, which reveal the importance of Spain in industrial technology, one of the most neglected sectors and on which the legend of the Spanish industrial incapability has been built (Thirsk 1978).

\section{Agents And Networks}

What was the character of these networks and how did they function? It is impossible not to relate all of these technological developments to the commercial expansion taking place in this epoch. Trade networks were essential in that they created or accompanied the need for the introduction of new technologies. As it is well known, commerce activated the desire for foreign goods and then, in a second phase, processes of import substitution or the flow of inventions and know-how due to the emigration of artisans. But this is only a part of more complex mechanisms, and on many occasions, commercial webs were embedded in more multifaceted processes.

The case of Monardes and the way he gave Europe knowledge of many American plants through his publications is very meaningful. This Seville-based doctor obtained most of these plants-which were the sources for the diffusion of new products, such as tobacco, cocoa and others, as well as their cultivation techniques-thanks to the commercial networks created by his family and the possibilities to travel to America or to acquire its products that they facilitated. But this case is also an example of the strong intertwining between merchants and more general and diffuse social and intellectual webs, in this case with a scientific component.

The guaranies that the Jesuits used to defend their territory against invasion and disorder became familiar with Western military technology not through arms trafficking, but because of the direct actions of the members of this religious order, who provided them with such technology and even obliged them to use it (Svriz 2016). As in the case of Monardes, the commercial interests and the financial networks-of the Fugger and Welser in this case-were of great importance for the introduction of new inventions in American mining (Kellenbenz 1999). But Crown action, rather than the purchase of technology, was the key for 
such a process. The artisans of Brihuega did not sell their expertise to be transported to Puebla (Altman 2000). But the way they transferred their technology was partially provoked by migrations which were linked to an incipient labour market.

The circulation and diffusion of technology took place through many different types of agents. The pleas of a Sevillian priest as he offered military inventions to the king are very indicative of something that was in fact more common than he himself might have thought (Pérez-Mallaína Bueno 1983). Medical practitioners, soldiers, priests, traders, nobles and bureaucrats could play a crucial role in the transmission of technological knowledge and, hence, it would be a mistake to focus only on artisans or technicians to understand the process. The Hieronymites were responsible for introducing the techniques for sugar production to the Antilles by bringing inventions already proven in the Canary Islands, the Azores and Madeira. The Jesuits were crucial for the diffusion of cultivation techniques for yerba mate in some areas of South America.

It is also important to consider that the spread of new technology was the consequence of the interaction between these informal networks and the more formal institutions created by the crown. The Supreme Council of the Indies belonged to the latter and derived from it its competencies in the production of scientific and technological knowledge and the control of its diffusion into America (Schafer 2003: 351-379). But this institution was embedded in the networks that pilots, cosmographers and seamen created among themselves, which had some degree of autonomy from the king's institutions. The American universities which have been seen as nodal points in the intertwining among theoretical knowledge and natural history on the one hand and more empirical knowledge and technological practices on the other hand (Osorio 2006) depended on very informal social and intellectual webs of knowledge, in spite of their character as very formalized institutions.

We could continue, but that would only be useful to show something that is already known: the network approach is more useful when it focuses on the actions of mediators than when it aims at classification of the character of the web. As it has been noted, 'the agency operating in networks cannot be defined as a profession but as a function' (Cools et al. 2006: 9). This is important since there is a temptation among technology historians to define a priori the types of mediators to analyse. 
This is, at best, an anachronism. It is grounded in the analysis of societies where technology constitutes very restrictive knowledge and the inventions' property right system strongly conditions circulations of knowledge that are very much based on the commercialization of technology. But, in the epoch that we are studying, much of the technological knowledge circulated through 'weak ties' and multifaceted networks (Granoveter 1973). These were very informal webs characterized by their low efficiency in implementing coercion and their high efficiency in circulating information.

\section{Empire, Control of Knowledge and Globalization}

This last feature of the social network through which technological information circulated facilitates a better understanding of the relations between technology and power as well as between globalization and empire. Although those relations can be studied from different perspectives, let me discuss only some of the possibilities.

As Goodman states, it is not clear whether the Inquisition was interested in the control of technological innovations. The many available studies on the Holy Office, as it was called in this era, do not show a clear interest in it. It is also interesting to note that the period of most intense activity of the Inquisition-between 1500 and the 1560scoincides with the most dynamic epoch of inventions and technological improvements. But the fact remains that micro-history studies do show something substantial: the obviously negative effects of the Holy Office's actions in limiting individual creative thinking. Carlo Ginsburg's study (1980) on the case of Menocchio is very significant in this respect. These effects must have been even worse given the interrelationship between theoretical developments, which were very much exposed to the Inquisition actions, and empirical thinking, which was crucial for scientific progress. We also need to ask to what extent the 'pedagogy of fear' promoted until the 1560 s was more effective in the following decades, when a very negative atmosphere was created that thwarted possible initiatives in the decades to come.

The enormous interest of the Spanish crown in controlling the circulation of technological knowledge is also well known. It has a parallel in the attempt to establish a commercial monopoly. But it is also a reflection of the fact that Philip II, like all princes of the epoch-any maybe beyond this-was aware of information's huge possibilities. He knew the 
importance of controlling, stocking, classifying and using [information or data perhaps?] for the ruling of his vast empire. The foundation of the Simancas Archive or of the Library of the Escorial may be the best proof of this awareness. For America, all this coincided with Ovando's reforms in the Supreme Council of the Indies based on the idea of ruling after considering all the information ('entera noticia') on all events (Brendecke 2009).

This perception of the relationship between power and technology explains why the Council of the Indies was immediately endowed with the supervision of the inventions transferred to America (PérezMallaína Bueno 1983: 36-54). A system close to a patents register was soon implemented by the Council. The procedure was little more than a transposition to the American regions of the arbitrismo's practices (YunCasalilla 2016). Very similar to the English projectors of monopolies, the method consisted of the registration of an invention in exchange for a royal privilege to implement it for a period of time.

This was a mechanism by which royal policy conditioned-it is difficult to say to what extent-the lines of technological development. Innovations in fields like cartography, navigation, mining and even medicine (an instrument to avoid demographic decline) were prioritized over other possible paths for progress (Schafer 2003: 351-379). Within these fields, some priorities also existed. The advancement in silver mining had stronger support than sectors such as iron mining and others. One of the leading specialists on the subject has even written that this explains 'the failure of the very wide interest in mining that existed in Spain during the 1560s' (Gómez 1989: 727). We should not be too rigorist when judging this aspect. These criteria can be explained by the epoch's bullionist perception of wealth, according to which prosperity was narrowly associated with the abundance of gold and silver. It has to be noted that we are considering a monarchy whose main and most urgent problem was fiscal and financial, and for which getting hold of easy money in the short run was more important than fomenting national wealth like the classical economists would prefer two centuries later. But the development of these fields of knowledge created synergies with many others. The foundation of the Academy of Mathematics by Philip II, for example, was most probably a consequence of his immediate needs, yet it must have had an impact beyond such short-term purposes. However, it is no less true that this emphasis on some fields filtered the allocation of talent and the opportunities of recognition for creative people. 
It is equally interesting to come back to the way in which the control of knowledge was implemented through 'patents', which were in fact privileges for the use of inventions. As we have tried to prove in previous work, there was no significant difference between the so-called first patents and the way in which hundreds of arbitristas negotiated their advice, opinions (pareceres), news and arbitrios, some of them really excentric, with the king (Yun-Casalilla 2016). A well-known case of an arbitrio such as that of the credit institutions promoted by Luis Valle de la Cerda and the Dutch Peter Oudegherste shows how patronage networks in the court could be more decisive for its success than the quality of the project (Dubet 2000: 11-31; 2003). The dynamics of rivalry, patronage, interest groups and clientelism could be more important than the actual quality of the project or invention. As a result, the problems of obtaining the necessary support by the promoters of inventions must have increased by the end of the century, when the courtly patronage system became heavier and even more corrupt than before. Moreover, the extreme obsession of the 'inventors' with secrecy shows that they operated in a context of great uncertainty in which avoiding intellectual piracy and gaining some benefit from their own work and inventiveness was extremely difficult (García Tapia 1990). This fact becomes clearer if we consider that the privilege of monopoly, after being so arduously achieved, guaranteed the inventor's ability to implement his discovery, but did not recognize the benefits of further sale after that privilege expired. All these were disincentives for technological development that most likely increased during the seventeenth century. It is true that some of these problems were present in other countries and that the models might differ. The Dutch system was likely to have been more capable of guaranteeing inventors' rights and consequently more efficient in allowing technological development in many possible directions (Buning 2014; Davids 2000: 263-283). But the Spanish scheme does not differ much from the English projectors' system, which was also criticized at home. Consequently, the Spanish system cannot be considered an anomaly, but rather an example of behaviours that spread throughout Europe. The procedure for registering technological novelties was far from a system of creating a genuine patent market that guaranteed the inventors' property rights. What we could call the political economy of technology was becoming less and less competitive in terms of reinforcing creativity and progress to the degree that was necessary in a global empire. 
All this goes against the image of an absolute and parasite monarchy aborting the development of society, in this case by controlling technological practices. More than a parasite, Philip II has been rightly presented as a promoter of technology (Goodman, 1988). Though within his own interests and schemes, like most rulers in history, he really tried to develop some specific fields of knowledge. This is very meaningful also on the relationship between power and technology in the Hapsburg monarchy. Many historians disagree with the idea of Acemoglu, Johnson and Robinson that the king's tyranny elevated the uncertainty and transaction costs of economic activities in creating insecure property rights. I would even argue that a very high degree of negotiation led to the maintenance of local and corporatist privileges (Yun-Casalilla, 2012) and that this was the reason for high transaction costs within the Iberian peninsula. The same could be said about the property rights and uncertainty associated with technological development: they were threatened not by royal tyranny but, rather, by the clientele's dynamics and the fragmentation of power inherent to the court system.

What has been said here is important to explain the relationship between empire and globalization from the history of technology's perspective. As we have noted above, the Iberian empires were powerful agents of globalization. This was the case in part due to their ability to recycle knowledge, which is a way of generating it. But it is also obvious that technological globalization itself weakened these empires. The networks of weak ties through which the ideas circulated created great difficulties to control knowledge and technology. Today we know that the commercial monopoly of the Indies was a chimera, an impossible wish. The same could be said of the attempts to control technological knowledge as a means to maintain power or leadership. Science and technological expertise flowed in circuits which were impossible to control. Indeed, they travelled beyond the empire, thus providing the king's enemies with the resources to confront him. We have referred to the little-studied transfer of knowledge from Castile to England, but we still need to add that those industrial technologies that travelled to England contributed to the increasing competitiveness of English products in Spain and the British capacity to take over the Mediterranean markets. More examples could be added. Many years ago, Herman Van der Wee (1967) illustrated the importance of sophisticated financial techniques originally developed in Castile for Northern Europe's business success. Two of the most knowledgeable specialists in the history of 
the Netherlands have made it clear that the great advances in the Dutch shipbuilding industry were made possible thanks to techniques imported from Spain (De Vries and A. Van der Woude 1997).

The same would apply to the imperial territories. Technological advances introduced in the colonies facilitated conquest and domination, as well as their systematic exploitation, but they also expanded the possibilities of autonomy from the crown and of political negotiation with it. The crucial role of Asian objects-a typical result of this first wave of globalization-in creating a Creole identity, neither Spanish nor American, has been recently stressed by José Luis Gasch (2012), which would be the basis for political and social negotiation of the Mexican elite with Madrid. Something similar could be said of the extraordinary capacity of introducing new technologies shown by the American elites in sectors such as the production of sugar or silver mining, thanks to which they reinforced their power and their capability to negotiate with the centre of the empire. If trying to control trade was a chimera, aspiring to a monopoly of technological knowledge was like attempting to restrain the ocean's water with one's hands. That is also why one needs to take a step back from these views of the relations between empire and technology that underline only the latter as a mechanism for imperial domination. Furthermore, the globalization of technology associated with imperial exploitation has also contributed to weaken those empires. Globalization and empires are two interlinked realities, but they do not always work in the same direction.

Assertions about Spain's total disregard and incapacity for technological development closely resemble the Black Legend and it does not make sense to return to them. Furthermore, we need to underline the very positive achievements of this country in the sixteenth century. But we also need to reflect on the limits of this model's capacity to generate technical development because of its biases, filters and methods. On the other hand, the emphasis on the role of Philip II as a promoter of technology in some particular fields, though has to be nuanced, is correct. However, in order to understand the complex reality of the epoch, it is also necessary to look not only at formal institutions created by the crown, but also at informal social and intellectual networks which were behind the transference of knowledge and technological improvement.

I would like to end by coming back to Masson's ideas. I think that contemporary research has render them outdated, as they belong to an 
old-fashioned and nationalistic view which concives scientific and technological progress within narrow national frameworks and forgets the transnational arena in which, then as today, knowledge evolves. There have been - and still are-countries able to create formal institutions capable of producing technological advances. Some of them, if not all, have also aimed to use technology as an instrument for political, economic and social dominion over others. But it is no less true that science and technology have also advanced thanks to transnational and very informal contacts. Sometimes those contacts and the transfers among the different agents have been almost imperceptible, as it is shown by the history of plagiarism and imitation. From this perspective, the contribution to the scientific revolution of the webs of knowledge that crossed the Iberian world is evident and has to be better identified. It is in any case palpable that there are many reasons to approach the problem in a way that substantially differs from that of the Black Legend's tradition.

\section{Notes}

1. See among many others, Mauro 1960.

2. I am grateful to the author for letting me use his work.

3. On this from a more general perspective, see Kamen (2003).

4. For some nuances on these ideas, see Portuondo (2014).

\section{ReFERENCES}

Acemoglu, D., S. Johnson, J. Robinson. 2005. "The Rise of Europe: Atlantic Trade, Institutional Change and Economic Growth." American Economic Review 95: 546-579.

Altman, I. 2000. Transatlantic Ties in the Spanish Empire: Brihuega, Spain of Puebla, Mexico, 1560-1620. Standford: Standford University Press.

Aram, B. and Yun-Casalilla, B. (eds.). Global Goods and the Spanish Empire, 1492-1824. Basingstoke: Palgrave.

Bakewell, P.J. 1976. Minería y sociedad en el México colonial. Zacatecas 15461700. Mexico: Fondo de Cultura Económica.

- 1989. Mineros de la Montaña Roja. Madrid: Alianza.

Brendecke, A. 2009. Imperium und Empirie: Funktionen des Wissens in der spanischen Kolonialherrschaft. Köln: Böhlau.

Buning, M. 2014. Privileged Knowledge: Inventions and the legitimization of knowledge in the early Dutch Republic (ca. 1581-1621). Florence: PhD diss. European University Institute of Florence. 
Cools, H. M. Keblusek and Noldus B. 2006. "Introduction. Profiling the early modern Agent." In Your Humble Servant. Agents in early Modern Europe, eds. Hans Cools, Marika Keblusek and Badeloch Noldus, Hilversum: Uitgeverij Verloren.

Davids, K. 2000. "Patents and patentees in the Dutch Republic." History and Technology, no. 16: 263-283.

de Vries, J. and A. Van der Woude. 1997. The First Modern Economy: Success, Failure, and Perseverance of the Dutch Economy, 1500-1815. Cambridge: Cambridge University Press.

Dubet, A. 2000. "El arbitrismo como práctica política: el caso de Luis Valle de la la Cerda ('1552?-1606)." Cuadernos de Historia Moderna 24: 11-31.

- 2003. Hacienda, arbitrismo y negociación politica. Los proyectos de erarios públicos y montes de piedad en los siglos XVI y XVII. Valladolid: Servicio de Publicaciones de la Universidad de Valladolid.

Eamon, W. 2009. "Nuestros males no son constitucionales, sino circunstanciales: The Black Legend and the History of Early Modern Spanish Science." The Colorado Review of Hispanic Studies 7: 13-30.

García Tapia, N. 1990. Patentes de inversión española en el Siglo de Oro. Madrid.

Gasch, J. L. 2012. Global trade, circulation and consumption of Asian goods in the Atlantic World: The Manila galleons and the social elites of Mexico and Seville (1580-1640). Ph.D. Thesis, European University Institute : Florence.

Ginzburg, C. 1980. The Cheese and the Worms: The Cosmos of a Sixteenth-century Miller. London : Routledge \& Kegan Paul.

Goodman, D. C. 1988. Power and Penury. Government, technology and science in Philip II 's Spain. Cambridge: Cambridge University Press.

Headrick, D. R. 2010. Chapter II. Power over peoples. Cambridge: Cambridge University Press.

Kamen, H. 2003. Empire: How Spain Became a World Power, 1492-1763. New York: Harper Collins.

Kellenbenz, H. 1999. Los Fugger en España y Portugal hasta 1650. Salamanca: Junta de Castilla y León.

Masson de Morvilliers, Nicolas, 1782. Espagne. Encyclopédie méthodique ou par ordre des matières. Géographie moderne, vol. I, París: Panckoucke.

Mauro F. 1960. Le Portugal et l'Atlantique au XVIIe siècle. Étude économique. Paris: SEVPEN.

Pérez-Mallaína Bueno, P.E. 1983. "Los inventos llevados de España a las Indias en la segunda mitad del siglo XVI." Cuadernos de Investigación Histórica 7: $36-54$.

Portuondo, M. 2014. "America and the Hermeneutics of Nature in Renaissance Europe." In Global Goods and The Spanish Empire, 1492-1824, eds. B. Aram \& B. Yun Casalilla, 78-99. New York: Palgrave-Macmillan. 
Osorio, A. B. 2006. Experiencing Nature: The Spanish American Empire and the Early Scientific Revolution. Austin: University of Texas Press.

Russell-Wood, A.J.R. 1998. The Portuguese Empire, 1415-1808. A World on the Move. Baltimore: John Hopkins University Press.

Saldarriaga, G. 2011. Alimentación e identidades en el Nuevo Reino de Granada, siglos XVI y XVII. Bogotá: Editorial Universidad del Rosario.

Sánchez Gómez, J. 1989. De Minería, metalúrgica y comercio de metales. La mine ría no férrica en el Reino de Castilla, 1450-1610. Salamanca: Universidad de Salamanca.

Schafer, E. 2003. El Consejo Real y Supremo de las Indias. La labor del Consejo de Indias en la administración colonial, vol. II, 297-298. Salamanca: Junta de Castilla y León y Marcial Pons.

Svriz, P. M. O. 2016. "La introducción de armas de fuego en las reducciones jesuíticas del Paraguay (s.XVII).” en América en la Primera Globalización: introducción y recepción de productos externos. Workshop held in Seville, October 6-7 (Unpublished paper).

Thirsk, Th. 1978. Economic Policy and Projects. The Development of a Consumer Society in Early Modern England. Oxford: Clarendom Press.

Van der Wee, H. 1967. 'Anvers et les innovations de la technique financière aux XVIe et XVIIe siècles'. Annales ESC, 22: 94-101.

Yun-Casalilla B. 2012. "Las instituciones y la economía política dela Monarquía Hispánica (1492-1714), Una perspectiva trans-nacional." In Economía politica desde Estambul a Potosí. Ciudades estado, imperios y mercados en el Mediterráneo y en el Atlántico ibérico, c. 1200-1800, eds. B. Yun Casalilla y F. Ramos, 11-38. Valencia: Universidad de Valencia.

Yun Casalilla, B. 2014. "The Spanish Empire, Globalization, and Cross-Cultural Consumption in a World Context, c. 1400-c. 1750." In Global Goods and The Spanish Empire, 1492-1824, eds. B. Aram and B. Yun Casalilla, 277-308. New York: Palgrave-Macmillan.

Yun-Casalilla, B. 2016. 'Arbitristas, Projectors, Eccentrics and Political Thinkers. Contextualizing and “Translating” a European Phenomenon'. In Reforming Early Modern Monarchies: The Castilian Arbitristas in Comparative European Prespectives, eds. S. Rauschenbach and C. Windler, 101-122. Wiesbaden: Harrassowitz Verlag.

Zanetti, C. 2017. JJanello Torriani and the Spanish Empire A Vitruvian Artisan at the Dawn of the Scientific Revolution. Leiden: Brill. 
Open Access This chapter is licensed under the terms of the Creative Commons Attribution 4.0 International License (http://creativecommons.org/licenses/ by $/ 4.0 /)$, which permits use, sharing, adaptation, distribution and reproduction in any medium or format, as long as you give appropriate credit to the original author(s) and the source, provide a link to the Creative Commons license and indicate if changes were made.

The images or other third party material in this chapter are included in the chapter's Creative Commons license, unless indicated otherwise in a credit line to the material. If material is not included in the chapter's Creative Commons license and your intended use is not permitted by statutory regulation or exceeds the permitted use, you will need to obtain permission directly from the copyright holder.

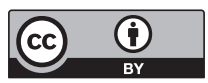

